International Journal of Biology, Pharmacy and Allied Seiences (IJBPAS) 'A Bridge Betuen Caboratory and Qnendo'

Www.ijbpas.com

\title{
A REVIEW ON PROTEASE
}

\section{PUROHIT $A^{1}$, ANDHARE $P^{2}$, MARCHAWALA $F^{2}$, BHATTACHARYA $I^{2}$, UPADHYAY ${ }^{2 *}$}

1: Student, M. Sc. Microbiology, Parul Institute of Applied Sciences, Parul University, Post Limda,

$$
\text { Waghodia, Gujarat, } 391760
$$

2: Assistant Professor, Parul Institute of Applied Sciences, Parul University, Post Limda, Waghodia, Gujarat, 391760

*Corresponding Author: Dr. Dhwani Upadhyay; E Mail: dhwani.updhyay82123@paruluniversity.ac.in;

Tel: +919558021474

Received 21 ${ }^{\text {st }}$ Jan. 2021; Revised 23 ${ }^{\text {rd }}$ Feb. 2021; Accepted $24^{\text {th }}$ March 2021; Available online $1^{\text {st }}$ April 2021

https://doi.org/10.31032/IJBPAS/2021/10.4.1030

\begin{abstract}
Protease is one of the most widely used enzymes in industries like detergents, food, leather and pharmaceuticals. Proteolysis occurs by breaking the peptide fraction and amino acid.Proteolytic chemicals are available in all life forms and contribute to cellular development and separation. Proteases are hydrolytic compounds that convert to biocatalysts for protein cleavage in peptides and amino acids. Micro-organisms have ended up being a capable and cost-effective well spring of antacids protease proteins that can provide a persistent and regular inventory of the desired item. Basic proteases have a wide application in different mechanical parts, particularly in cleaning and calf companies. However, their application to food has not been widely abused. This study describes all the reports on the uses of basic protease in various areas with a basic view on the applications of food.
\end{abstract}

\section{Keyword: Proteases, sources, application}

\section{INTRODUCTION}

Proteases are important industrial catalysts that are used in a variety of industrial applications [1]. Proteases are currently used in the detergent, food, pharmaceutical, and animal skin industries [2]. Moreover, they have applications in silver recovery from 
photographic plates and amide synthesis [3]. Protease is a proteolytic catalyst enzyme that produces less pollution than chemical catalysts and performs reactions with greater specificity. Protease is the most important catalyst, accounting for one-third of all enzyme sales worldwide. Most industrial processes are capable of functioning in adverse conditions; therefore, it is critical to have microorganism enzymes that exhibit the best activities in adverse conditions. Though proteases are common in nature, microbes are the most common source of those enzymes due to their magnificence, restricted space required for cultivation, and ease of genetic manipulation, with which they'll supply new enzymes with altered properties that area unit desired for their various applications. In accordance with their activities, enzymes are acidic, neutral, or alkaline. Alkaliphilic proteases are important in the detergent industry. Acidophilous proteases, on the other hand, play an important role in the tanning of animal skin, the food industry, and the removal of sliver from x-ray films. Microorganism proteases, particularly those derived from bacteria, have historically dominated the industrial catalyst market, catalyst sales, with a significant application in detergent formulations. Numerous microorganisms that have been screened for use in a variety of industrial applications, primarily strains $B$. subtilis and B. licheniformis, have been discovered to be a dominant and prolific supply of alkalic proteases [4]. Microorganism alkalic proteases are distinguished by their high activity at alkalic pH scale (i.e., $\mathrm{pH} 10$ ) and broad substrate specificity. The ideal temperature for them is around $60^{\circ} \mathrm{C}$. These properties of microorganism alkalic proteases are alkaline, they can be used in the detergent industry.The catalyst is widely distributed in nature, appearing in a wide range of microorganisms, plant and animal tissues. Microorganisms are thought to be the most effective source of alkalic enzyme for industrial use. The major cluster manufacturing enzyme was discovered among the various microorganisms.

\section{STRUCTURE OF PROTEASE}

Alkaline proteases have 3 functional domains as a serine protease attached to subtitles group with the given functional residue [5]. Subtilase is a huge large family of serine protease and serine proteases whose Catalytic movement is facilitated by a charge relay structure, similar to that of the trypsin family of serine proteases, which evolved through autonomous convergent evolution. Tertiary structure of a protein is assembled by 
packing of its secondary structure element to form discrete domains.

\section{CLASSIFICATION OF PROTEASE}

Proteases are widely categorized in two groups: [1] exopeptidase [2] endopeptidase according to to their action at or away from the termini respectively.

Proteases are enzymes that hydrolyze protein peptide bonds. Exopeptidases are enzymes that break the terminal amino acid residue at the end of a polypeptide, whereas endopeptidases break the internal peptid bonds. These peptidases are further classified according to the chemical groups that function in catalysis. The hydroxyl group on the side chain of a serine residue in the active site acts as a nucleophile in the reaction that hydrolyzes a peptide bond in serine proteases, whereas the sulfhydryl group on the side chain of an a cysteine performs this function in cysteine proteases. In aspartic acid proteases and metallo proteases, a water molecule in the active site acts as a nucleophile, attacking the peptide binding site [6].

\section{SOURCE OF PROTEASE}

Researchers from a range of microbial sources have been able to produce proteases. Microbes account for two-thirds of the global protease trade [7]. Because of their high yield, less time consumption, less space required, high genetic manipulation, and cost efficiency, the proteases available on the market are of microbial origin, allowing them to be applied biotechnologically on the market [8].

\section{Protease from plant}

The formulation of plant proteins such as bromelain, keratinase and ficin is timeconsuming.Papain is a former protein plant that encompasses a long history of usage. It is extracted from the latex of melon tree fruits grown in the climatic zones of west and central Africa, as well as India [9]. Because of the presence of several peptidase and isozymes, the crude preparation of the enzyme has a broader specificity. The protein is active between pH 5 and 9 and stable up to $80^{\circ} \mathrm{C}$ or $90^{\circ} \mathrm{C}$ in the presence of substrates. Bromelain is extracted from pineapple stems and juice. The protein is classified as an amino acid proteinase and is active at $\mathrm{pH}$ levels ranging from 5 to 9 [9].

\section{Protease from animal}

The proteases of the pancreas, trypsin, pepsin, chymotrypsin and rennin are the animal proteases which have produced and disposed of enormous quantities of pure form in Chymotrypsine is found in the animal exocrine gland. It is a milk macromolecule. It is widely used in the de-allergenicization of the gland as a precursor, chymotrypsinogen, 
and is activated by multiple enzymes in a multi-step method. Pepsin is found in almost all vertebrate stomachs. [9].

\section{Protease from microbes}

Because plant and animal proteases are unable to meet current global demands, interest in microbial proteases has increased. It involves bacteria, fungi and viruses. Bacillus organisms are primarily responsible for the production of alkaline and neutral proteases. Bacterial neutral protease is active at specific $\mathrm{pH}$ levels ranging from 5 to 8 and has a low thermos resistance. Pseudomonas, for example, is a gram-negative bacteria. They all produce different proteolytic enzymes which have been purified and characterized [9].

Table 1: List of microbes producing proteases

\begin{tabular}{|c|c|c|}
\hline Microorganism & Types of protease & References \\
\hline \multicolumn{3}{|l|}{ BACTERIA } \\
\hline Aeromonas salmonicidaA-7301 & Alkaline & [9] \\
\hline Arthrobacter aureus & Endo serine & [9] \\
\hline Bacillus alclophilusPB92 & Alkaline & [10] \\
\hline Bacillus amyloliquefaciens & Alkaline ane neutral & [11] \\
\hline Bacillus brevis HPD 31 & Serine & [11] \\
\hline Bacillus pumilus strain MK6-5 & Alkaline & {$[12]$} \\
\hline Bacillus subtilis & Alkaline neutral and acidic & [13] \\
\hline Pseudomonas fluorescens P 26 & Heat stable & [14] \\
\hline Pyrococcusfuriosus & Serine & [15] \\
\hline \multicolumn{3}{|l|}{ FUNGI } \\
\hline Aspergillus flavus var. columnaris & Alkaline and neutral & [16] \\
\hline Mucor pusillus strain S7 407 & Two acid, one alkaline & [17] \\
\hline Streptomyces rectus var. proteolyticus & Alkaline & [18] \\
\hline Xanthomonas campestrispv. & Serine & [19] \\
\hline \multicolumn{3}{|l|}{ YEAST } \\
\hline Aureobasidium pullulans & Alkaline & [20] \\
\hline Candida digboensisSRD yeast 1 & - & [21] \\
\hline Candida humicola & Acid & [21] \\
\hline Saccharomycopsislipolytica & Alkaline & [22] \\
\hline \multicolumn{3}{|l|}{ PROTOZOA } \\
\hline Rumen protozoa & $\begin{array}{c}\text { Cysteine and less extent aspartic } \\
\text { proteinase }\end{array}$ & [23] \\
\hline
\end{tabular}

\section{APPLICATIONS:}

Microbial proteases have many applications in the following industries,

\section{Protein hydrolysis:}

In the food industry proteases are used to modify, palatability and shelf life of all available protein sources. High nutritional value protein hydrolysate formulations are obtained by the use of alkaline proteases. In meat tenderization, microbially derived alkaline proteases are extremely important [24].

Food and feed industry: 
During the production of cheese from milk, proteases are added to hydrolyzed kappa casein to prevent coagulation by the formation of stabilize micelles. In the bakery industry, for faster's dough preparation, its gluten is partially hydrolyzed by a heat-labile fungal proteases due to its early inactivation in subsequent baking. The high nutrient protein hydrolysate preparation was accomplished by the addition of microbial alkali proteases. This hydrolysate preparation is essential to the preparation of infant foods and to the enrichment of soft drinks and juices [25]. Mackerel hydrolysatic has helped to hydrolysate protein molecules into free amino acids, including carosine, anserine and other small peptides through the use of proteases.

\section{Waste management:}

The use of chemicals in industries is environmentally harmful. This dangerous use of chemicals requires an eco-friendly alternative to waste treatment. Poultry feathers containing highly rigid keratin make up $5 \%$ of body weight and are a rich source of protein for food and feed. Poultry waste may be broken down into feed and food by the keratinolytic process [20]. For hair removal and cleaning of drains and obstructed pipes, a formulation containing hydrolytic enzymes isolated from B. subtilis,
B. amyloliquefaciens and Streptomyces $s p$. was developed and patented as genex.

\section{Leather industry:}

The increased application of alkaline protease in emerging leather industries is due to elastolytic and keratinolytic activity. These influential properties of alkaline proteases are highly effective in the leather manufacturing industries. The specific uses of protease are relevant in the soaking, release and depilation stages of skin and skin preparation. The elimination of unwanted pigments by enzymatic easements helps the production of clean skin. Pancreatic protease enzyme processes rely on the bating system. Alkali microbial proteases have become very popular in the leather sector [22].

\section{Detergent industry:}

Proteases are widely used in the laundry industry for commercial purposes. Proteasecontaining detergents have been used to clean household linens, dentures, and contact lenses. Proteases account for approximately $20 \%$ of total enzyme sales in the detergent industry. The NOVO A/S industry in proteases from $B$. cereus introduced alcalase with the trade name BIOTEX produced by $B$. licheniformis to the market [24]. BMI is said to be an effective detergent. Traditionally, detergents operate at high temperatures, but there has been a surge of interest in the study 
and identification of alkaline proteases that operate at a wide range of temperatures.

\section{Medical field:}

In medicine, various formulations containing alkaline proteases produced by $B$. subtilis, such as gauze, nonwoven tissue, and ointment composition, have promising therapeutic properties. Oral administration of alkaline proteases has been shown to help some lytic enzyme deficiency syndrous [25]. It has been reported that alkali fibrinolytic protease can degrade fibrin.In therapeutic applications, the preparation in slow release dosage form containing collagenase and alkaline proteases is widely used. A preparation of elastoterase immobilised on the bandage increased proteases used for the treatment of various diseases such as burns, boils, and injuries.

\section{CONCLUSION}

Bacterial proteases are a type of hydrolytic enzyme that has been commonly used since the advent of enzymology. It has a wide range of uses in the detergent industry, bioremediation, food processing, and leather processing, and has been widely commercialized by a variety of companies around the world. The production of these enzymes has been improved significantly by the utilization of cheaply available agro industrial wastes, hyper-producing strains and genetically modified bacteria. New technology implementation is necessary to promote cleaner production in every industry especially leather and treatment industries by replacing most traditional chemical methods with inexpensive and eco-friendly alternative especially proteases. The higher official and any responsible body give more attention and enforce the investor for cleaner production in order to mitigate the risk of our environments.

\section{ACKNOWLDGEMENT}

It's our privilege and honour to express our sincerest gratitude to the Parul University, Vadodara, Gujarat for providing me all the necessary support and facilities including state of the art infrastructural facilities with advanced technological scientific laboratories and everything else that was required to carry out this work.

\section{REFERENCES}

[1] Binod Parameswaran, Piyush Palkhiwala et al; "Industrial enzymespresent status and future perspectives for India." May 2013; 72: 271-286.

[2] Aravindan Vanchiappan, Joe Gnanaraj et al; "Lithium-ion conducting electrolyte salts for lithium batteries." Chemistry-A European Journal. Dec 2011; 17(51): 14326-14346. 
[3] Mehta, V. J., J. T. Thumar, and S. P. Singh. "Production of alkaline protease from an alkaliphilic actinomycete." Bioresource technology. Sep 2006; 97(14): 16501654.

[4] Kumar, C. Ganesh, and Hiroshi Takagi. "Microbial alkaline proteases: from a bioindustrial viewpoint." Biotechnology advances.1999; 17(7): 561-594.

[5] Rao, Mala B., Aparna M. Tanksale, et al; "Molecular and biotechnological aspects of microbial proteases." Microbiology and molecular biology reviews .Sep 1998; 62(3): 597-635.

[6] Rao, Kiranmayee, and M. Lakshmi Narasu. "Alkaline protease from Bacillus firmus 7728. "African Journal of Biotechnology. Nov 2007; 6(21): 2493-2495.

[7] Olajuyigbe, Folasade M., and Joshua O. Ajele. "Production dynamics of extracellular protease from Bacillus species." African Journal of Biotechnology.aug 2005; 4(8): 776779 .

[8] Nisha, N. S., and J. Divakaran. "Optimization of alkaline protease production from Bacillus subtilis NS isolated from sea water." African Journal of Biotechnology. Apr 2014; 13(16): 1707-1713.

[9] Sharma, Divakar, and Deepa Bisht. "M. tuberculosis hypothetical proteins and proteins of unknown function: hope for exploring novel resistance mechanisms as well as future target of drug resistance." Frontiers in microbiology. Mar 2017; 8: 465.

[10] Haandrikman, Alfred J., Rene Meesters et al; "Processing of the lactococcal extracellular serine proteinase." Applied and Environmental Microbiology. Jul1991; 57(7): 1899-1904.

[11] Vasantha, N., L. D. Thompson, "Genes for alkaline protease and neutral protease from Bacillus amyloliquefaciens contain a large open reading frame between the regions coding for signal sequence and mature protein." Journal of bacteriology. Sep1984; 159(3): 811-819.

[12] Varambally, Sooryanarayana, Saravana M. Dhanasekaran et al; "The polycomb group protein EZH2 is involved in progression of prostate cancer." Nature. Jul 2002; 419, (6907): 624-629. 
[13] Brown, Rodney J., C. A. Ernstrom, and Mark E. Johnson. "Milk-clotting enzymes and cheese chemistry." In Fundamentals of dairy chemistry, Springer, Boston, 1988; 609-654.

[14] Mayerhofer, H. J., R. T. Marshall. et al; "Characterization of a heat-stable protease of Pseudomonas fluorescens P26." Applied microbiology. Jan 1973; 25(1): 44-48.

[15] Ernest, C. Steven, Stephen D. Hall."Mechanism-based inactivation of CYP3A by HIV protease inhibitors." Journal of Pharmacology and Experimental Therapeutics. Oct 2005; 312(2): 583-591.

[16] Impoolsup, Attawut, Amaret Bhumiratana, and Timothy W. Flegel. "Isolation of alkaline and neutral proteases from Aspergillus flavus var. columnaris, a soy sauce koji mold." Applied and environmental microbiology. Oct 1981; 42(4): 619-628.

[17] Rao, Kiranmayee, and M. Lakshmi Narasu. "Alkaline protease from Bacillus firmus 7728." African Journal of Biotechnology.Nov2007; 6(21): 2493-2495.
[18] Mizusawa, Kiyoshi, EijiIchishima. "Production of thermostable alkaline proteases by thermophilic Streptomyces. "Applied microbiology. Mar 1969; 17(3): 366-371.

[19] Dow, J. Maxwell, Belinda R. Clarke."Extracellular proteases from Xanthomonas campestrispv. campestris, the black rot pathogen." Applied and environmental microbiology. Oct 1990; 56(10): 2994-2998.

[20] Ma, Chunling, Xiumei Ni. "Purification and characterization of an alkaline protease from the marine yeast Aureobasidium pullulans for bioactive peptide production from different sources." Marine Biotechnology. Mar 2007; 9(3): 343-351.

[21] Patel, Hardik, Akshaya Gupte. "Effect of different culture conditions and inducers on production of laccase by a basidiomycete fungal isolate Pleurotusostreatus HP-1 under solid state fermentation." BioResources. 2009; 4(1): 268-284.

[22] Simms, PAULA C., and DAVID M. Ogrydziak. "Structural gene for the alkaline extracellular protease of Saccharomycopsis lipolytica. Journal of bacteriology. Jan 1981; 145(1): 404409. 
[23] Forsberg, CECIL W., L. K. Lovelock, L. Krumholz "Protease activities of rumen protozoa." Applied and environmental microbiology. Jan 1984; 47(1): 101-110.

[24] Vishwanatha, K. S., AG Appu Rao."Characterisation of acid protease expressed from Aspergillus oryzae $\quad$ MTCC 5341." Food Chemistry. Sep 2009; 114 (2): $402-$ 407.

[25] Mishra, Tulsi Das, Hemal Kurani. "Simultaneous Quantitation of HIVProtease Inhibitors Ritonavir, Lopinavir and Indinavir in Human Plasma by UPLC-ESI-MSMS." Journal of chromatographic science. Aug2012; 50(7): 625-635. 